\title{
Posted Workers Directive 96/71/EC in the Framework of Free Movement of Services
}

\author{
Dr. Senada Reçi \\ University “Luigj Gurakuqi” Shkoder, Albania; sreci@unishk.edu.al
}

\author{
Doi:10.5901/mjss.2016.v7n3p44
}

\begin{abstract}
This paper aims to analyze Directive 96/71 on posted workers which regulate an aspect of free movement of services, that of moving workers from one state to another state within the movement of services. Provisions of directive 96/71 aim to remove obstacles and uncertainties and limitations that affect the implementation of the free movement of services in the displacement of workers from one country to another. Issues Laval, Viking, and interpretation of the jurisprudence of the ECJ occupy a prominent place in this paper, after serving as guides for the implementation of the Directive by the Member States, as well as various conflicts between national legislation regarding the status of displaced workers and their rights provided by the Directive.
\end{abstract}

Keywords: posted workers, free movement of services, directive 96/71, social dumping, employment.

\section{Introduction}

Directive $96 / 71 / \mathrm{EC}$ is a directive that regulates an aspect of free movement of services, that of moving workers from one state to another state within the movement of services.

This Directive aims to remove obstacles and uncertainties that affect the implementation of the free movement of services and to enhance legal certainty by identifying the working conditions applicable to workers who carry out temporary work in a Member State other than the State whose legislation regulates employment (So the directive is part of the European program for the realization of an integrated market for services and provides the answer to the legislative requirements of the social implications of this program. It brings a new form of movement of workers, which differs significantly from the movement of migrant workers and explicitly regulated by the treaty and community acts in connection with the free movement of workers. Bano.F., 2008: 141-142). The Directive has met the need of adjustment request phenomenon interstate movement of labor in a service format by creating a climate of fair competition between companies. In this case, the definition of the working conditions applicable to posted workers expresses the request for a balance between economic freedoms and labor protections, given the prevention of social dumping, as a practice of employers using job cheaper than it was it is usually available in their country of production and sales. In the first case, migrant workers are employed, in the second production is moved to a state or area of lower wages. Entrepreneur so will save money and potentially increase its profit (Social dumping and market expansion in Europe, edited by Magdalena Bernaciak and forthcoming with Routledge, 2014).

A systematic review is of the consequence, as governments are tempted to enter a regime of the so-called competition of social policy where they will reduce their standards of labor and social issues to facilitate labor costs on companies and, eventually, to keep business activity within their jurisdiction.

\section{The Effects of Directive $96 / 71$ on the Free Movement of Posted Workers}

Social dumping on the free movement of posted workers and competition of social policy as the labor costs on enterprises brings consequences in the labor market. This affects the correct functioning of a competitive market within two directions:

a. the concerns of Member States at the time of implementation of national labor standards and $b$. the concept of territorial sovereignty itself, where the orientation of one or the other direction will lead to different interpretations.

So setting standards to protect the workforce employed in services is a move to avoid distorting the competitive market rules originating from social dumping practices. Meanwhile, according to a second interpretation setting of standards of labor protection for community enterprises accounts for the purpose of some Member States that want to 
maintain their markets to work and regulations of labor from foreign competition.

This interpretation is because the main beneficiaries of the discipline of the Directive on Posted Workers are Member States that make up the country of destination of delivery (https://www.etuc.org/sites/www.etuc.org/files/final_ report_etuc_expert_group_posting_310510_en.pdf).

But at the end of this logic we can say that none of the theses above is not absolute because it depends on the implementation or operation of the Directive in national legislation and coordination of its provisions with the doctrine of obstacles because ambivalence (the overall uncertainty) is inherent to the directive itself. So directive has its pragmatist goals, depending on the particular or concrete situation (Bano.F., 2008: 142-143; Posted workers: http://www.eurofound. europa.eu/areas/industrialrelations/dictionary/definitions/postedworkers.htm).

But to return to the scope of application and protection framework that aims to implement this directive let's analyze its content with the essential elements.

The first question that arises, in this case, is that what are displaced workers, whose legal regime governing this directive?

A posted worker is defined as a person who, for a limited period of time, performs his/her work in the territory of a member state of the EU, rather than the state in which he/she normally works (Article 2 of Directive 96/71: http://eurlex.europa.eu/lexuriserv/lexuriserv.do?uri=celex:31996l0071:en:html).

For example, a service provider may win a contract to work in another country to perform the contract and sends its workers there. This general provision of services, where employees are assigned to work in a Member State other than that in which they usually work, gives us a particular category, namely that of posted workers.

Definition used in several documents of the European institutions, regulations, and other states as the main features of the displacement of workers:

- a genuine employment relationship with the "original" employer, which means that the employee performs services for a fee to the company and in the wake of this relationship moved to another country to perform services but maintaining the original relationship by requests of which he/she moved.

- temporary nature of activities carried out, which means that workers are offering services within the free movement of services and not the freedom of establishment.

This category does not include migrant workers who go to another Member State to seek employment and to be employed there.

Posted worker qualification does not apply to:

- People who decide an agreement to look for work in another Member State,

- Personnel marine in merchant navy,

(http://www.maltachamber.org.mt/common/fileprovider.ashx?id=634453670675398750)

It should be noted that "the free movement of workers', which gives every citizen the right to move freely in another Member State to work and reside there for that purpose and protects them against discrimination, must be differentiated from the 'free movement of services" that gives businesses the right to provide services in another Member State, as is laid down in Article 56 TFEU (http://www.eurofound.europa.eu/observatories/eurwork/industrial-relations-dictionary/ posted-workers).

\section{Scope of the Directive $96 / 71 / E C$}

As workers moved to another Member State to work and reside protected by Directive 96/71/EC, it is understood that the protection is not defined in this movement.

Directive 96/71 covers workers being sent to another Member State in three situations:

i. When an enterprise located in a member state moved for its account and under its direction a worker in another Member State, under a contract that the company/employer has concluded with the party in the state in which there are intended services, so that while the relocation held a working relationship between the worker and the company that posted him. In this case, we shift worker to a client of his employer;

ii. When an employee in the enterprise transferred a worker to an institution or a group-owned enterprise in the territory of a Member State so that during the relocation held a working relationship between the worker and the company that moved/posted him/her. Here it is a casual shift worker productive activity within the enterprise that develops after missing a contract between the supply company and the beneficiary one;

iii. When the employer, being an industry or temporary employment agency hires a worker in a company established or operating in another Member State so that during the relocation held a working relationship between the posted worker and the company that has posted him/her. Here it comes to specialized 
enterprises for temporary employees and commitments to their displacement during the engagement.

It is worth noting that the concept interstate referred to the worker is narrower than the provision of services related to, as in the present case we have the displacement, the physical displacement of employees into the host State, a condition that is not required to the free movement of services, as there may be traffic services through telephone marketing lacking physical displacement of labor.

Another feature is that the shift is realized as existing before the relationship between employee and employer/company supplying the service, and not without this present existence.

As for identifying the scope of the directive, the host state law applies, the legislation of the Member State in whose territory the worker is moved to the service.

This interpretation has led some critics discussed by the jurisprudence of the ECJ, regarding the definition of minor or autonomous work in its decision C.255/04 Commission v.Repubblica Francese. The Court stated that assumption as a subordinate of the work of an artist from the French code was an obstacle to the free movement of services within the meaning of Article 56 TFEU.

In fact, the lack of the concept of worker leaves clear existing differences between different national arrangements in connection with the work dependent or independent of adverse consequences to the employee independently regarding country of origin, which included as dependents under rates of the host state. In this case, we have the twosided coin, the first posted workers will not have the protection of the directive and the second to different utilities would make them national unfair competition employing paid labor force. About the lack of the concept of employee and uncertainty framing legal because of the broad scope of work economically dependent existent in the member states, the Commission then analyzed and opened a public debate on the Green Book for the modernization of the proper working (Bano.F., 2008:143-189).

Directive 96/71 is not intended to harmonize the contents of national normative, as explicitly manifests the acceptance of legislation of the host state, but the coordination of the national legislative laws and choice of the law applicable to the protection of posted workers. Thus, the Directive 96/71 can be seen as an instrument of private international law aimed at identifying the law applicable in respect of a number of issues of labor law.

The Directive aims the conditions of work and employment, the maximum and the minimum of rest, health, safety and hygiene at work, deadlines holiday payable including overtime, protective measures for pregnant women and those who had children, equality of treatment of men and women and other non-discrimination provisions. The only issue that is not subject to harmonization via directives is the minimum wage and posted workers for overtime charges after wages that don't fall under the Community law regulation.

Directive expresses the principle of equal treatment of workers and posted local workers since non-discrimination clause is community-based and freedoms enshrined by the TFEU.

One important reference the directive makes to the collective contract, although its involvement in regulatory resources for posted workers presented complications given the heterogeneity of models of collective bargaining, in the Union Member States (such as Italy, Sweden, UK, Denmark, Malta).

These EU Member States do not know the effect erga omnes, and thus the reference to the directive does not apply in the case of national directive transposition, in the absence of which in the case of a contract does not use conditions of work and employment of posted workers, but national provisions.

The ECJ in the case Laval in reference to Swedish legislation where contracts have no effect erga omnes opposed this by creating a lot of controversy. The controversy was after stating that Article 56 TFEU and the directive in question prevent a union organization through collective action to compel a service provider located in another Member State to begin a negotiation for the payment of bonuses to posted workers to sign an agreement clause which provides more favorable conditions than those stemming from the labor provisions (ibid). Regarding social security regime will apply the principle of country of origin launched by the temporality of residence in the state where the posted worker is, that is equal to 12 months (ibid: 190-195).

Another point where the guidelines intersect with private international law, norms on conflicts of jurisdiction and competence. This issue is resolved in a uniform way at European level through Regulation 44/2001/EC, which stipulates that in a case of conflict, the employer has the right to claim only the judge of the Member State in which territory the posted worker resides. When the worker make the lawsuit he has several options:

- $\quad$ before the judge of the Member State in which the employer resides

- before a judge of the country in which the worker usually conducts its activities in that country or the last country in which usually develop it

- the judge of the country in which it is or was near the seat of activity which is hiring (Ibid: 184-185).

But within the context of this analysis, it is worth to mention that the displacement of workers is prevalent in the 
construction industry, but also in telecommunications, transport, repairs, maintenance and service. While it 's hard to calculate the exact number of posted workers, data from a report funded by the European Commission in 2011 show that based on certificate E101, had 1,294,669 displaced workers in 27 EU countries in 2007. The main countries sending workers were France, Poland and Germany (In 2011 and 2012, they organized several discussions about posted workers, which includes several MEPs, political parties and representatives of the social partners. Proposal for a Directive regarding the implementation of the provisions applicable to the displacement of workers in the framework of the supply of services - COM (2012) 131; Proposal for a Regulation on the exercise of the right to take collective action within the context of the economic freedoms of the single market - COM (2012) 130; Commission document: Impact Assessment, Review of the legal framework regarding the relocation of workers in the context of service delivery.- SED (2012): Posted workers http://ec.europa.eu/social/main.jsp?catld=471\&langld=en).

Meanwhile, the Commission has taken some initiatives recently about the problems caused by how the legislation regarding posted workers is adopted and implemented.

\section{Effects of the ECJ Jurisprudence; Issues Laval, Viking, and Other}

The ECJ has tried a series of cases relating to the provision of labor on a temporary basis by a service provider from one Member State and governed by Directive 96/71 of posted workers (for which the European Commission issued a statement that provided guidance for its implementation referring to the consequences of the jurisprudence of the ECJ decisions).

For parts covered by it, the Court has referred to the provisions on services to complement the vacuum to lawsuits filed before it with object the provision of manpower.

In principle, a Member State may conduct his work legislation on workers and employees including non-citizens of the EU to a company (society) that provides temporary work.

However the principle of proportionality, setting the conditions as requiring a license (permit) work is acceptable only if there are no requirements to double by the State of establishment (country of origin) and taking into account the relevant evidence and guarantees provided by the service provider in the host country as in the case 279/80 Webb.

In all cases, when a case brought by the host country that makes legal restrictions reasonably protect posted workers should be examined in details, as in case 113/89 Rush Portuguesa, 43/93 Vander Elst, etc (Reçi.S.,2013: http://www.doktoratura.unitir.edu.al/wp-content/uploads/2014/01/Doktoratura-Senada-Reci-Fakulteti-i-DrejtesiseDepartamenti-i-te-Drejtes-Publike).

Most recognized and most contested case on posted workers is Laval, which was reviewed by the ECJ shortly after the Viking case (Case 341/05, Laval un Partneri Ltd :http://curia.europa.eu/ju/showPdf.jsf?text=\&docid=71925\& pagelndex=0\&doclang=EN\&mode=Ist\&dir=\&occ=first\&part=1\&cid=741396_).

ECJ decided that a conflict of labor in the form of a blockade by Swedish union workers against a Latvian company, that because of the lower cost of labor Lithuanians won a construction contract to undertake temporary work in Sweden where conflict work had as aimed at forcing the company to sign a collective agreement in Sweden that contained conditions of work and other conditions of employment, was not justified under Article 56 TFEU (Chalmers. D.,Davies.G.,Monti.G.,2010: 803; Craig.P.,De Burca.G., 2011: 802-803). The court based its decision on the Directive 96/71 on Posted Workers in which Sweden could have chosen putting legal minimum working conditions on Latvian company or declared universally applicable collective agreement, although the Swedish system of labor relations was defined as decentralized forecasting through collective bargaining wage setting rates.

This case has generated significant controversy in Sweden and across Europe, as it includes not only splitting the Swedish model so popular and social, placing it against the economic freedoms of the Treaty, but also in the context of the diversity of new economic and social Union as a result of the expansion of the East [i.e., the countries of Central and Southeastern Europe which come from the old communist or socialist and having inherited its elements in the social system or social security] pointing out economic disparities between the different countries of the EU.

While this trial has been widely criticized because it gives priority to free movement of economic harm to collective bargaining freedoms and the lack of judgment as incorrect adds Latvian workers rights in the country to minimize Swedish workers' rights (Case 438/05, Viking:http://curia.europa.eu/jcms/upload/docs/application/pdf/2009-02/cp070088 en.pdf).

The Court to Laval gave not the appropriate national court to apply the proportionality test but decided lack of justification of collective action (Chalmers.D.,Davies, G.Monti.G., 2010: 803-804). The Court recognizes that, in the context of an agreement seeking to regulate paid work collectively, the provisions on freedom of establishment give rights to a private company that can be relied on against a trade union or an association of trade unions exercise their powers 
of independent, to negotiate with employers or professional organizations the conditions of employment and salary workers.

Subsequently, the Court notes that the conditions laid down for the registration of vessels must not form an obstacle to freedom of establishment.

First, collective action such as that envisaged by FSU has the effect to make it less attractive, or pointless, the exercise of the free establishment by Viking Line of its right to freedom of establishment, given that such action prevents the Viking Line and its subsidiary Estonia to enjoy the same treatment in the host member state as other economic operators established in that country.

Secondly, collective action taken to implement the policy for combating the use of flags of convenience, requires, first, to prevent owners of vessels from the registration of ships in a country different from that of the citizen who are beneficial owners of these ships. The ECJ stated that such action constituted a restriction on freedom of establishment (Case 438/05, Viking: http://curia.europa.eu/jcms/upload/docs/application/pdf/2009-02/cp070088en.pdf).

While on the status of workers providing services to citizens of third countries, we can give as an example the case of Rush Portuguesa (Case 113/89 Rush Portuguesa: eurlex.europa.eu/smartapi/cgi/sga_doc?smartapilcelexplus!prod! CELEXnumdoc\&numdoc $=61989 \mathrm{~J} 0113 \& \mathrm{lg}=e n)$.

The case concerned a Portuguese company of construction and public works called "Rush Portuguesa," which had become a sub-contracting with a French company for some work that would accomplish in France, and the company in question within the performance of the subcontract had brought from Portugal to France its workers. But the French inspection services accused the Portuguese society of infringing the French Labor Code, as workers brought from Portugal, had no work permit from the National Immigration Office. The ECJ in its decision point 18 stated: Workers employed by an undertaking established in a Member State, who are temporarily sent to another Member State, in order to perform a service, are not intended to enter in the labor market in the second state, but they will return to their country of origin or residence after completion of their mission (See also: http://arbetsratt.juridicum.su.se/filer/pdf/niklas\% 20bruun/eup.11.11.services.nb.pdf).

The inability of posted workers to third-country nationals, in the place where relocating to work, relates to the boundaries where lies the entirety of the provisions of Directive 96/71. They can not be recovered as citizens of third countries with this Directive when they want to work even after the relocation contract.

\section{Conclusions}

The status of posted workers in another Member State from that where they are located within the delivery of services is governed by Directive $96 / 71$.

The main feature of this Directive the relationship of good employment with the 'original' employer, means that the employee performs services for a fee to the company and in the wake of this relationship moved to another country to perform services but maintain the original relationship by requirements which shifted.

This directive provides for the application of the principle of country of origin for the protection of posted workers and does not include migrant workers who go to another Member State to seek employment and to be employed there.

Cases Laval, Viking and others deemed by the ECJ provide a clearer interpretation of the provisions of Directive 96/71 and conflicts rates implemented provisions of the Directive or misapplying interpretations of Member States. After these decisions national courts of member states have coverage of detailing to the provisions of the directive to protect the status of posted workers.

\section{References}

Social dumping and market expansion in Europe, edited by Magdalena Bernaciak and forthcoming with Routledge, ETUI aisbl, Brussels, 2014.

Reçi.S. Lëvizja e lirë e shërbimeve në Tregun Unik Evropian dhe perspektiva në kuadër të zgjerimit të Bashkimit Evropian, doktoratura, 2013 http://www.doktoratura.unitir.edu.al/wp-content/uploads/2014/01/Doktoratura-Senada-Reci-Fakulteti-i-Drejtesise-Departamenti-ite-Drejtes-Publike.

Craig.P., De Burca.G., EU law text cases and materials, fifth edition, Oxford University Press 2011.

Chalmers.D,Davies.G.,Monti.G.,European Union Law, second edition, Cambridge University Press, 2010.

Bano.F.,Diritto del lavoro e libera prestazione dei servizi nell Unione europea, II Mulino Bologna, 2008.

Directive 96/71/EC of the European Parliament and of the Council of 16 December 1996 concerning the posting of workers in the framework of the provision of services, http://eur-lex.europa.eu/lexuriserv/lexuriserv.do?uri=celex:31996l0071:en:html.

Case 113/89 Rush Portugues: eurlex.europa.eu/smartapi/cgi/sga_doc?smartapi! celexplus!prod!CELEXnumdoc\&numdoc=61989J0113 


\section{\&lg=en.}

Case 341/05, Laval un Partneri Ltd, http://curia.europa.eu/ju/showPdf.jsf?text=\&docid=71925\&pageIndex=0\&doclang=EN\&mode=|st\& dir=\&occ=first\&part=1\&cid=741396.

Case 438/05 Viking http://curia.europa.eu/jcms/upload/docs/application/pdf/2009-02/cp070088en.pdf/http://curia.europa.eu/juris/show Pdf.jsf?text=\&docid=71495\&pagelndex=0\&doclang=en\&mode=Ist\&dir=\&occ=first\&part=1\&cid=741704

Posted workers; www.eurofound.europa.eu/areas/industrialrelations/dictionary/definitions/postedworkers.htm.

Posted workers http://ec.europa.eu/social/main.jsp?catld=471\&langld=en/http://arbetsratt.juridicum.su.se/filer/pdf/niklas\%20bruun/eup. 11.11.services.nb.pdf

http://www.maltachamber.org.mt/common/fileprovider.ashx?id=634453670675398750 .

http://www.eurofound.europa.eu/observatories/eurwork/industrial-relations-dictionary/posted-workers 